\title{
Pre-soaking with gibberellin in sweet corn seed lots with different levels of vigor
}

\section{Pré-embebição com giberelina em lotes de sementes de milho doce com diferentes níveis de vigor}

\author{
Jéssica de Lucena Marinho1*; Altamara Viviane de Souza Sartori2; \\ Evandro João Rodrigues ${ }^{1}$; José Henrique Bizzarri Bazzo; \\ André Sampaio Ferreira4; Claudemir Zucareli ${ }^{3}$
}

Highlights

The physiological quality of sweet corn seeds was benefited by pre-soaking.

Pre-soaking favored seed germination in a water-deficit condition.

Pre-soaking with water favored the performance of vigorous seeds.

Pre-soaking with $0.4 \mathrm{~g} \mathrm{~L}^{-1}$ gibberellic acid favored non-vigorous seeds.

\begin{abstract}
The poor longevity and performance of sweet corn seeds justify the adoption of practices that enhance their quality, such as pre-soaking. Thus, this study aimed to evaluate the effects of pre-soaking with gibberellin on the physiological potential of two sweet corn seed lots with contrasting vigor levels under ideal and waterdeficit conditions. Initially, the seed lots were characterized for germination and physiological potential through first count, germination, accelerated aging, cold test, normal seedling length, normal seedling dry mass, field emergence, emergence speed index, and tetrazolium test. Subsequently, the seeds were pre-soaked with water and 0.4 and $0.8 \mathrm{~g} \mathrm{~L}^{-1}$ gibberellic acid, in addition to the control (without pre-soaking), randomly in a $2 \times 4$ factorial scheme with four replications. Then, the moisture content, first count, germination, field emergence, and emergence speed index of the seeds were evaluated under conditions of simulated water deficiency. The data obtained were subjected to analysis of variance and comparison of means, using Tukey's test and Student's t-test, for comparisons between treatments and lots, respectively. Pre-soaking favored germination speed and percentage in sweet corn seeds, particularly under water-deficit conditions. Pre-soaking the most vigorous lot with water and the least vigorous lot with $0.4 \mathrm{~g} \mathrm{~L}^{-1}$ gibberellic acid favored the physiological performance.
\end{abstract}

Key words: Germination. Special corn. Vigor. Water deficiency. Zea mays.

1 Doctoral Students in Agronomy, State University of Londrina, UEL, Londrina, PR, Brazil. E-mail: jlmarinho@live.com; evandro_agro@hotmail.com

2 Masters Student in Agronomy, UEL, Londrina, PR, Brazil. E-mail: altamarasartori@gmail.com

3 Profs. Drs., Department of Agronomy, UEL, Londrina, PR, Brazil. E-mail: josebazzo@uel.br; claudemircca@uel.br

4 Post-Doctoral in Agronomy, UEL, Londrina, PR, Brazil. E-mail: andresampaioferreira@gmail.com

* Author for correspondence

Received: Apr. 29, 2020 - Approved: Dec. 28, 2020 


\section{Resumo}

A reduzida longevidade e o baixo desempenho de sementes de milho doce justificam a adoção de práticas que potencializem sua qualidade, como a pré-embebição. Neste sentido, objetivou-se avaliar os efeitos da pré-embebição com giberelina no potencial fisiológico de dois lotes de sementes de milho doce, com níveis de vigor contrastantes, em condições ideais e de estresse hídrico. Inicialmente, os lotes de sementes utilizados foram caracterizados quanto a germinação e potencial fisiológico - através dos testes: primeira contagem, germinação envelhecimento acelerado, teste de frio, comprimento de plântulas normais, massa seca de plântulas normais, emergência em campo, índice de velocidade de emergência e teste de tetrazólio. Posteriormente, as sementes foram submetidas a diferentes tratamentos de pré-embebição, em delineamento inteiramente casualizado, em esquema fatorial $2 \times 4$, com quatro repetições, sendo dois lotes e quatro tratamentos de pré-embebição: com água e com solução de ácido giberélico à $0,4 \mathrm{~g} \mathrm{~L}^{-1}$ e à 0,8 $\mathrm{g} \mathrm{L}^{-1}$, além do controle (sem pré-embebição). Em seguida, as sementes foram submetidas aos testes de primeira contagem e germinação em condições de deficiência hídrica simulada, além dos testes de grau de umidade, primeira contagem, germinação, emergência em campo e índice de velocidade de emergência. Os dados obtidos foram submetidos a análise de variância e comparação de médias, pelo teste de Tukey e pelo teste t de Student, para comparação entre os tratamentos e os lotes, respectivamente. A pré-embebição favoreceu a velocidade e porcentagem de germinação das sementes de milho doce, principalmente em condições de déficit hídrico. A pré-embebição somente com água, no lote de maior vigor, e com ácido giberélico à 0,4 $\mathrm{g} \mathrm{L}^{-1}$, no lote de menor vigor, favorece o desempenho fisiológico das sementes avaliadas.

Palavras-chave: Germinação. Milhos especiais. Vigor. Déficit hídrico. Zea mays.

\section{Introduction}

Sweet corn (Zea mays convar. saccharata), widely cultivated and used as green corn, is basically intended for human consumption in fresh, processed, and dehydrated forms and as baby corn (Luz, Camilo, Barbieri, Rangel, \& Oliveira, 2014). The great use of this maize group is due to some of its specific characteristics such as thin pericarp, uniform grain and seed texture, high sugar content, and good palatability, which are attributed to the genes that block sugar conversion into starch in the endosperm (Souza et al., 2013).

Although these characteristics favor commercialization for human consumption, they hinder quality seed production, since the reduced pericarp thickness and high sugar amount favor mechanical damage, pest and pathogen infestation, and deterioration (Storck, Lovato, \& Comassetto, 1984). Therefore, these seeds have poor storage potential and low vigor, which affects the establishment and uniformity of the plant stand in the field (Mondo, Cicero, Dourado, Pupim, \& Dias, 2012).

The poor performance and longevity of sweet corn seeds justify the adoption of techniques that preserve and enhance their quality. Pre-soaking, a process that consists of water absorption, which results in tissue rehydration, stands out as a tool to benefit seed quality, as it promotes breathing intensification and the resumption of other metabolic activities, providing energy for embryonic axis growth and development (Rabbani, Silva-Mann, Ferreira, \& Vasconcelos, 2013), which improves the percentage, speed, 
and uniformity of germination and seedling emergence in the field (Marcos \& Kikuti, 2008).

Thus, this technique minimizes the effects of unfavorable environmental conditions due to the reduced exposure of seeds to adverse conditions (Santos, SilvaMann, Ferreira, \& Brito, 2011) and pest and micro-organism attack, in addition to providing increased competitiveness with weeds (Pereira, Dias, Dias, \& Araújo, 2009), which ensures success in initial crop establishment.

Seed pre-release has been carried out in the presence of plant regulators such as gibberellin (Bezerra, Medeiros, Bruno, \& Momenté, 2006; Peixoto, Sales, Vieira, Passos, \& Santos, 2011; Lopes \& Souza, 2008). Gibberellin is considered a hormone according to Taiz \& Zeiger (2013), among hormones present in seeds, with a wide spectrum of action because it influences several processes involved in plant development, such as germination, growth by elongation, and other functions (Pimenta, Carvalho, Carvalho, Dantas, \& Aragão, 2010).

Gibberellin stimulates the germination process in seeds with or without dormancy by activating the vegetative growth of the embryo, which occurs due to endosperm reserve mobilization (Taiz \& Zeiger, 2013), thus favoring the growth and establishment of plants. Lima et al. (2020) evaluated the development and production of sweet corn from seeds treated with bio-stimulants containing gibberellin and found that the phytomoniums applied favored the crop.

In addition, pre-soaking, combined with gibberellin application, may favor seed germination under stress because this treatment, in addition to stimulating the activation of proteolytic enzymes that promote reserve material hydrolysis, also induces tolerance to water deficiency in seeds and seedlings (Chen, Arora, \& Arora, 2010). This is because it promotes tissue hydration, reducing the amount of water absorbed at the beginning of growth, which considerably increases germination speed and percentage (Aragão et al., 2003).

However, despite the numerous advantages of pre-soaking, associated or not with growth regulators such as gibberellin, many difficulties are still observed, particularly due to the variability of results among species, cultivars, and even seed lots. In this context, the adequacy of the best pre-release technique for sweet corn, particularly the solution to be used, is fundamental.

Hence, this study aimed to evaluate the effects of pre-imbibition with gibberellin on the physiological potential of two sweet corn seed lots with contrasting vigor levels under ideal and water stress conditions.

\section{Materials and Methods}

Two batches of hybrid super sweet corn seeds (SV9298SN ${ }^{\circledR}$; Performance Series ${ }^{\text {TM }}$ Single Pro $\mathrm{SC}^{\mathrm{TM}}$ ) carrying the shrunken gene (sh2) and with contrasting vigor levels were developed by artificial aging at $35^{\circ} \mathrm{C}$ for 0 (high vigor lot) and 24 (low vigor lot) h.

First, the initial physiological quality of the two seed lots was characterized. A germination test was conducted with eight replicates of 50 seeds sown on germination paper (Germitest ${ }^{\circledast}$ ) wetted with distilled water in a proportion of 2.5 times the dry paper mass. The paper rolls were kept in a germinator previously maintained at $25^{\circ} \mathrm{C}$, and the normal seedling count was performed 4 (first count [FC]) and 7 (final count [G]) days after sowing 
(DAS) (Ministério da Agricultura, Pecuária e Abastecimento [MAPA], 2009), and the results are expressed as percentages.

For accelerated aging (AA), $11 \mathrm{~cm} \times 11$ $\mathrm{cm} \times 3.5 \mathrm{~cm}$ individually compartmented plastic boxes with lids were filled with $40 \mathrm{~mL}$ distilled water, and a metallic screen was fixed to pack the seeds. Four replicates of 120 seeds for each lot were aged at $42^{\circ} \mathrm{C}$ for $72 \mathrm{~h}$. Then, eight germination rolls with 50 seeds for each lot were prepared according to the methodology described for the germination test (MAPA, 2009), and the results were evaluated at 4 DAS and are expressed as a percentage.

The cold test (CT) was conducted using the paper roll methodology (Cícero \& Vieira, 1994) with four replicates of 50 seeds. The rolls were incubated at $10^{\circ} \mathrm{C}$ for 7 days. Then, the rolls were transferred to the germinating machine maintained at $25{ }^{\circ} \mathrm{C}$; the normal seedling count was performed 4 DAS, and are expressed as percentages.

Seedling length was determined from four replicates of 10 seeds per lot, with the upper third of the germination paper being dampened with distilled water in the proportion of 2.5 times the mass of the dry substrate. The rolls were maintained in the dark at $25{ }^{\circ} \mathrm{C}$ for 4 days. Then, normal seedlings were measured and separated into shoot and root parts; the results are expressed in centimeters by seedling.

The dry mass of the seedlings was also evaluated using the normal seedlings used in the length test. Briefly, the seedlings were separated into shoots and roots, packed in paper bags, and stored in a greenhouse with forced air circulation at $80 \pm 5{ }^{\circ} \mathrm{C}$. The mass of each seedling was measured using a scale (precision $0.001 \mathrm{~g}$ ); the average mass is expressed in grams $(\mathrm{g})$ per seedling.

To obtain the variable field emergence (FE), four replicates of 100 seeds each were sown at a depth of $4 \mathrm{~cm}$ in beds with a distance of $10 \mathrm{~cm}$ between each other. The number of seedlings with normal shoot development at 15 DAS was recorded; the result is expressed as a percentage.

The test for the emergence speed index (ESI), expressed in (\%), was conducted in conjunction with the seedling emergence test in the field, and seedling counts were cumulatively recorded daily. Thus, the emergence speed indexes (ESI) were calculated from the number of seedlings emerging daily (Maguire, 1962).

The tetrazolium test was conducted using four replicates of 50 seeds per batch, preconditioned on germination paper (Germitest ${ }^{\circledR}$ ) moistened with distilled water in a proportion of 2.5 times the dry paper mass for $24 \mathrm{~h}$ at $25^{\circ} \mathrm{C}$. After preconditioning, the seeds were sectioned longitudinally and transversally through the embryo (one of the parts was discarded). Then, the samples were immersed in $0.1 \%$ tetrazolium solution and kept in a germination chamber at $35{ }^{\circ} \mathrm{C}$ for $3 \mathrm{~h}$ in the dark. After staining the seeds, the solution was drained, and the seeds were washed and immersed in water until evaluation. Viability results were obtained from the means of the numbers of seeds in classes 1 and 2, according to Dias and Barros (1995).

The selected lots presented contrasting vigor levels according to the results of the initial characterization (Table 1), the first having high vigor and the second having low vigor.1 
Table 1

Characterization of initial physiological potential of the lot of sweet corn seeds (Zea mays convar. Saccharata)

\begin{tabular}{cccccccccccc} 
Lot & $\begin{array}{c}\mathrm{FC} \\
(\%)\end{array}$ & $\begin{array}{c}\mathrm{G} \\
(\%)\end{array}$ & $\begin{array}{c}\mathrm{AA} \\
(\%)\end{array}$ & $\begin{array}{c}\mathrm{CT} \\
(\%)\end{array}$ & $\begin{array}{c}\mathrm{SL} \\
(\mathrm{cm})\end{array}$ & $\begin{array}{c}\text { SR } \\
(\mathrm{cm})\end{array}$ & $\begin{array}{c}\text { DMS } \\
(\mathrm{g})\end{array}$ & $\begin{array}{c}\text { DMR } \\
(\mathrm{g})\end{array}$ & $\begin{array}{c}\text { FE } \\
(\%)\end{array}$ & $\begin{array}{c}\text { ESI } \\
(\%)\end{array}$ & $\begin{array}{c}\text { TZ } \\
(\%)\end{array}$ \\
\hline High vigor & $60 \mathrm{a}$ & $89 \mathrm{a}$ & $44 \mathrm{a}$ & $49 \mathrm{a}$ & $13.77 \mathrm{a}$ & $20.91 \mathrm{a}$ & $0.019 \mathrm{a}$ & $0.014 \mathrm{a}$ & $84 \mathrm{a}$ & $15.72 \mathrm{a}$ & $92 \mathrm{a}$ \\
\hline Low vigor & $31 \mathrm{~b}$ & $64 \mathrm{~b}$ & $9 \mathrm{~b}$ & $20 \mathrm{~b}$ & $8.39 \mathrm{~b}$ & $15.86 \mathrm{~b}$ & $0.009 \mathrm{~b}$ & $0.004 \mathrm{~b}$ & $65 \mathrm{~b}$ & $11.52 \mathrm{~b}$ & $75 \mathrm{~b}$ \\
\hline p-valor & 0.00 & 0.00 & 0.00 & 0.00 & 0.00 & 0.00 & 0.00 & 0.01 & 0.00 & 0.00 & 0.03 \\
CV & 16.45 & 3.76 & 17.68 & 14.31 & 14.54 & 5.89 & 21.53 & 30.61 & 13.84 & 16.67 & 3.45
\end{tabular}

Means followed by the same letter in the columns do not differ according to Student's t-test $(P \leq 0.05)$.

Coefficient of variation (CV), first germination count (FC), germination (G), accelerated aging (AA), cold test (CT), shoot length (SL), seedling root (SR), dry mass of shoot (DMS) and root (DMR) of seedlings, field emergency (FE), emergency speed index (ESI), and tetrazolium test (TZ).

After characterizing the initial physiological qualities, the seeds in the two lots were pre-soaked with pure water or 0.4 or 0.8 $\mathrm{g} \mathrm{L}^{-1}$ gibberellic acid solution, in addition to the control (without pre-imbibition). A completely randomized experimental design was used in a $2 \times 4$ factorial scheme (two seed lots and four treatments), with four replicates.

The two gibberellic acid solutions were obtained by diluting 0.40 and $0.80 \mathrm{~g}$ gibberellic acid in $1 \mathrm{~L}$ water, respectively. Seed pre-soaking was performed with four replicates of 200 seeds per treatment, spread on germination paper previously wet with gibberellic acid solutions and pure water in a proportion of 2.5 times the dry paper mass and packed in a germinator for $24 \mathrm{~h}$ at $25^{\circ} \mathrm{C}$ (Moreira et al., 2014).

Soon after the treatments, the seeds were subjected to FC, G, FE, and ESI tests, according to the methodologies described above. The moisture content of the seeds was also determined using two repetitions of 4.5 $\mathrm{g}$ per treatment in a greenhouse regulated at
$105 \pm 2{ }^{\circ} \mathrm{C}$, for $24 \mathrm{~h}$, according to the Rules for Seed Analysis (MAPA, 2009).

In addition, the seeds were subjected to $F C$ and $G$ tests under simulated water deficiency conditions. For this purpose, wet germination paper was used, in a proportion of 2.5 times the mass of the dry substrate, with polyethylene glycol solution (PEG 6000), simulating water stress in an osmotic potential of $-0.4 \mathrm{Mpa}$. To obtain the PEG solution, the methodology proposed by Oliveira, Zucareli, Prete e Zamuner was used, and the salt amount needed to obtain -0.4 MPa osmotic potential was diluted in distilled water. The rolls made with PEG solution were kept in a germinator at $25^{\circ} \mathrm{C}$, and the normal seedlings were counted at 4 and 7 DAS (first count, FC-PEG and germination, G-PEG, respectively).

The data obtained were subjected to analysis of variance after the assumptions were verified. The means of the lots were compared using Student's t-test and the means of presoaking treatments using Tukey's test at $5 \%$ probability. 


\section{Results and Discussion}

Pre-soaking treatments significantly affected the first germination count in PEG solution (FC-PEG), germination in PEG solution
(G-PEG), germination (G), field emergence (FE), and emergence speed index (ESI) in the two seed lots. For the first count (FC), an isolated effect was observed for lots and treatments (Table 2).

\section{Table 2}

Mean square values of the variance analysis of the variables: first germination count in PEG solution (FC-PEG), germination in PEG solution (G-PEG), first germination count (FC), germination (G), field emergence (FE), and emergency speed index (ESI) in two sweet corn seed batches (Zea mays convar. Saccharata)

\begin{tabular}{cccccccc|}
$\begin{array}{c}\text { Variation } \\
\text { source }\end{array}$ & DF & FC-PEG (\%) & G-PEG (\%) & FC (\%) & G (\%) & FE (\%) & ESI \\
\hline Lot (L) & 1 & $2278^{* * *}$ & $7503^{* * *}$ & $7875^{* * *}$ & $2965^{* * *}$ & $4465^{* * *}$ & $281^{* * *}$ \\
\hline Treatments (T) & 3 & $868^{* * *}$ & $207^{* * *}$ & $1214^{* * *}$ & $220^{* * *}$ & $164^{* *}$ & $15,5^{* *}$ \\
\hline L*T $^{* *}$ & 3 & $67.5^{*}$ & $82.5^{*}$ & $24.1 \mathrm{~ns}$ & $58.2^{* *}$ & $153^{* *}$ & $10.5^{* *}$ \\
\hline Error & 24 & 14.5 & 19.2 & 23.5 & 8.33 & 30.9 & 2.22 \\
\hline CV & & 13.9 & 8.26 & 7.65 & 3.51 & 7.56 & 9.98
\end{tabular}

$\mathrm{DF}=$ degrees of freedom; $\mathrm{CV}=$ coefficient of variation. $\mathrm{ns},{ }^{*}{ }^{* *}{ }^{*}$, and ${ }^{* * *}=$ not significant, significant at $\mathrm{P} \leq 0.05, \mathrm{P} \leq 0.01$, and $\mathrm{P} \leq 0.001$, respectively, by the $\mathrm{F}$ test.

PC-PEG, which simulates the germination speed in a condition of stress due to water deficiency, was observed to be the highest in the high vigor seed lot presoaked with $0.4 \mathrm{~g} \mathrm{~L}^{-1}$ gibberellic acid, followed by treatment with $0.8 \mathrm{~g} \mathrm{~L}^{-1}$ gibberellic acid, which did not present significant differences in relation to the reduced $\mathrm{GA}_{3}$ concentration and only water. It is noteworthy that all preimbibition treatments were superior to the control in the high vigor lot. For the low vigor lot, PC-PEG was increased by pre-soaking with water or $\mathrm{GA}_{3}$; it was not significantly different between the treatments but was statistically superior to that in the control (Table 3).

G-PEG, which simulates the percentage of seed germination under water-deficient conditions, was increased in the high vigor lot after pre-imbibition treatments; it was superior to that after the control treatment. In contrast, for the low vigor lot, the highest and lowest germination percentages were obtained after pre-imbibition with water and with the control treatment, respectively. 
Table 3

Moisture (U), first count of germination in PEG solution (FC-PEG), germination in PEG solution (G-PEG), and germination (G) of high vigor (HV) and low vigor (LV) sweet corn seed lots (Zea mays convar. saccharata)

\begin{tabular}{|c|c|c|c|c|c|c|c|c|}
\hline \multirow{3}{*}{ Types of pre-soaking } & \multicolumn{2}{|c|}{ U (\%) } & \multicolumn{2}{|c|}{ FC-PEG (\%) } & \multicolumn{2}{|c|}{ G-PEG (\%) } & \multicolumn{2}{|c|}{$\mathrm{G}(\%)$} \\
\hline & \multicolumn{8}{|c|}{ Lot } \\
\hline & HV & LV & HV & LV & HV & LV & $\mathrm{HV}$ & LV \\
\hline Control & 8.11 & 8.39 & $17 \mathrm{cA}$ & 8 bB & $58 \mathrm{bA}$ & $33 \mathrm{bB}$ & $89 \mathrm{bA}$ & $64 \mathrm{cB}$ \\
\hline $\mathrm{H} 2 \mathrm{O}$ & 33.68 & 32.08 & $37 \mathrm{bA}$ & $20 \mathrm{aB}$ & $68 \mathrm{aA}$ & $43 \mathrm{aB}$ & $95 \mathrm{aA}$ & $75 \mathrm{bB}$ \\
\hline $0.4 \mathrm{~g} \mathrm{~L}-1 \mathrm{GA} 3$ & 33.33 & 33.90 & $47 \mathrm{aA}$ & $24 \mathrm{aB}$ & $76 \mathrm{aA}$ & $38 a b B$ & $94 a b A$ & $82 \mathrm{aB}$ \\
\hline $0.8 \mathrm{~g} \mathrm{~L}-1 \mathrm{GA} 3$ & 34.74 & 33.60 & $43 \mathrm{abA}$ & $25 \mathrm{aB}$ & $72 \mathrm{aA}$ & $38 a b B$ & $90 \mathrm{abA}$ & $71 \mathrm{bB}$ \\
\hline
\end{tabular}

Means followed by the same letters, uppercase in the row and lowercase in the column, do not differ according to Student's t-test and Tukey's test, respectively, at 5\% probability.

It was observed that for the high vigor seed lot, pre-soaking with water resulted in the highest percentage of germination, and the control had the lowest germination percentage value. The germination percentage obtained after the gibberellic acid treatments was not significantly different from that observed after the other treatments. For the low vigor lot, the highest germination percentage was observed after treatment with $0.4 \mathrm{~g} \mathrm{~L}^{-1}$ gibberellic acid, which was followed by those after treatments with $0.8 \mathrm{~g} \mathrm{~L}^{-1}$ gibberellic acid and water, which did not differ from each other but were superior to that in the control (Table 3).

Field emergence was not significantly different between different treatments in the high vigor lot. However, for the low vigor lot, the field emergence percentage was lower in seeds pre-soaked with water than in seeds subjected to other treatments. ESI was increased in the high vigor lot pre-soaked with both concentrations of gibberellic acid, and pre-soaking with water showed no significant difference from the other treatments. For the low vigor lot, a high ESI value was observed in seeds subjected to pre-soaking with $0.8 \mathrm{~g} \mathrm{~L}^{-1}$ gibberellic acid and the control, and the lowest value for this variable was observed after pre-soaking with water. The ESI value after pre-soaking with $0.4 \mathrm{~g} \mathrm{~L}^{-1}$ gibberellic acid did not differ from that after the other treatments (Table 4). 
Table 4

Field emergence (FE) and emergence speed index (ESI) in two lots of sweet corn seeds (Zea mays convar. saccharata)

\begin{tabular}{ccccc} 
& \multicolumn{3}{c}{ FE (\%) } & Lot \\
\cline { 2 - 5 } Types of pre-soaking & \multicolumn{3}{c}{ High vigor } & Low vigor \\
\cline { 2 - 5 } Control & $79 \mathrm{aA}$ & $65 \mathrm{aB}$ & $15.4 \mathrm{bA}$ & $12.5 \mathrm{aB}$ \\
$\mathrm{H}_{2} \mathrm{O}$ & $86 \mathrm{aA}$ & $51 \mathrm{bB}$ & $17.6 \mathrm{abA}$ & $9.60 \mathrm{bB}$ \\
$0.4 \mathrm{~g} \mathrm{~L}^{-1} \mathrm{GA} 3$ & $88 \mathrm{aA}$ & $65 \mathrm{aB}$ & $19.2 \mathrm{aA}$ & $12.0 \mathrm{abB}$ \\
$0.8 \mathrm{~g} \mathrm{~L}^{-1} \mathrm{GA} 3$ & $89 \mathrm{aA}$ & $67 \mathrm{aB}$ & $19.4 \mathrm{aA}$ & $13.7 \mathrm{aB}$
\end{tabular}

Means followed by the same letters, uppercase in the row and lowercase in the column, do not differ according to Student's t-test and Tukey's test, respectively, at 5\% probability.

The performance of the high vigor lot for all variables was better than that of the low vigor lot for all pre-release treatments and the control (Tables 3 and 4).

Although pre-imbibition allows seeds with different vigor levels to reach the same stage of development when they reach the same level of intake (Taylor et al., 1998), the percentage and speed of germination and emergence of seedlings of the two lots were significantly different, proving that, although pre-imbibition improves the viability and vigor of the two lots, this procedure did not approximate or standardize the physiological characteristics of the evaluated seeds. This is because the two evaluated lots presented distant and contrasting physiological qualities.
Pre-soaking treatments and the lots separately affected the first count of germination under ideal conditions. Similar to the other variables, the high vigor lot had a higher overall average than the low vigor lot. It was also higher in the high vigor lot pre-soaked with water than that after pre-imbibition with $0.8 \mathrm{~g} \mathrm{~L}^{-1}$ gibberellic acid, both of which were superior to that after the control treatment, which presented the worst performance. Presoaking with $0.4 \mathrm{~g} \mathrm{~L}^{-1}$ gibberellic acid did not result in a first count value different from that after the other two types of pre-imbibition; however, it was superior to the control. In the low vigor lot, the treatments that included presoaking were better than the control; however, no variation was observed between these prerelease treatments (Table 5). 


\section{Table 5}

\section{First germination count (FP) in two sweet corn seed lots (Zea mays convar. saccharata)}

\begin{tabular}{|c|c|c|}
\hline \multicolumn{3}{|c|}{ First germination count (\%) } \\
\hline \multirow{2}{*}{ Lot } & High vigor & Low vigor \\
\hline & 79 A & $48 \mathrm{~B}$ \\
\hline \multicolumn{3}{|c|}{ Types of pre-soaking } \\
\hline Control & $60 c$ & $31 \mathrm{~b}$ \\
\hline $\mathrm{H}_{2} \mathrm{O}$ & $90 \mathrm{a}$ & $54 a$ \\
\hline $0.4 \mathrm{~g} \mathrm{~L}^{-1} \mathrm{GA} 3$ & $87 a b$ & $56 a$ \\
\hline $0.8 \mathrm{~g} \mathrm{~L}^{-1} \mathrm{GA} 3$ & $80 \mathrm{~b}$ & $51 \mathrm{a}$ \\
\hline
\end{tabular}

Means followed by the same letters, uppercase in the row and lowercase in the column, do not differ according to Student's t-test and Tukey's test, respectively, at $5 \%$ probability.

The results obtained show the importance of the pre-imbibition of seeds under stress conditions because it induces tolerance to water deficiency in seeds and seedlings (Chen et al., 2010), considerably increasing germination speed and percentage. This is because pre-imbibition promotes the hydration of seeds as only the early stages of the germination process, phase I (characterized by rapid imbibition) and phase II (characterized by reduced water absorption), are completed, without completing phase III (characterized by primary root protrusion) (Bewley, Bradford, Hilhorst, \& Nonogaki, 2013), which can be confirmed by the moisture of the seeds (Table 3). When submitted to pre-soaking treatments the seeds presented about 33\% moisture (this moisture is characteristic of seeds that are in phase II of the germination process), unlike the control treatment that presents approximately $8 \%$ humidity, since it did not start the germination process (Carvalho \& Nakagawa, 2012; Bewley et al., 2013).

Santos et al. (2011), who studied moringa seeds (Moringa oleifera) under conditions of water stress caused by salt stress, found that pre-imbibition in water for
$24 \mathrm{~h}$ increased the physiological attributes evaluated, resulting in seeds with better vigor, compared to seeds that were not subjected to pre-imbibition. Similarly, Kaya, Okçu, Atak, Çikili, \& Kolsarici (2006) observed that the pre-soaking of sunflower (Helianthus annuus) seeds in distilled water, followed by drying, improved the germination percentage under PEG- and sodium chloride-imposed water stress conditions.

Chen et al. (2010) highlighted that pre-hydration suitable for each species can increase the tolerance of seeds to the water uptake reduction caused by water or salt stress. This is because this treatment may be related to the activation of stress protection mechanisms that include excessive reactive oxygen species accumulation and lipid peroxidation. Hu, Xie, Wang, \& Song (2006) reported that pre-imbibition significantly improves the activities of antioxidant enzymes, reducing the accumulation of malondialdehyde, a reactive product of lipid oxidation caused by stresses, such as water deficiency, which was also observed by Farhoudi, Saeedipour, \& Mohammadreza (2011). 
In addition, during pre-imbibition, several metabolic events that contribute to the improvement of germination are activated. The benefits of this procedure include the activation of macromolecular repair mechanisms and the membrane system, an increase in enzymatic activities, and the mobilization of sugars and proteins (Varier, Vari, \& Dadlani, 2010). These treatments activate enzymes responsible for the mobilization of reserve compounds such as $\alpha$ - and $\beta$-amylases (carbohydrates) and isocitrate lyase (lipids) and endospermweakening enzymes such as endo- $\beta$ mannanase (Anese et al., 2011).

In general, pre-soaking treatments, particularly the pre-soaking treatments with the two gibberellic acid concentrations tested were superior to the control for most of the variables evaluated, even those conducted under ideal conditions ( $G$ and $F C$ ), field conditions (FE and ESI), and those that simulate stress (PC-PEG and G-PEG), which overlapped in some situations.

Similar to the results observed, Oliveira, Silva-Mann, Santos, Gois and Barretto (2007) studied the effect of controlled pre-imbibition promoted by osmotic conditioning in sweet corn seeds stored for 6 months and found increased germination and improvements in the germination speed index in seeds that underwent the controlled imbibition process compared to the control seeds. These results also corroborate the findings of Rabbani et al. (2013), who analyzed the effects of presoaking moringa (Moringa oleifera Lam.) seeds with distilled water and found that it promotes seed viability and vigor.

Similarly, Bezerra et al. (2006) evaluated the effects of hydration and gibberellic acid application on the germination of macela
(Egletes viscosa (L.) Less.). seeds and observed that the pre-imbibition of seeds directly in water or substrate with GA3 increases germination percentage and speed and reduces the average germination time, corroborating the results obtained.

Pre-imbibition associated with gibberellic acid influences protein metabolism by stimulating $\alpha$-amylase and other proteolytic enzymes, which also promote hydrolysis of the reserve material, further favoring germination (Aragão et al., 2003).

Lopes \& Souza (2008) found that the presence of gibberellin in the imbibition solution, during the conditioning process, favored germination in papaya seeds, regardless of the procedure adopted, similar to the results obtained. Likewise, Peixoto et al. (2011) studied the effects of pre-soaking with and without gibberellin on castor bean seeds and observed the better physiological potential of the seeds pre-soaked with gibberellic acid.

Based on the results obtained, it can be stated that pre-soaking with water and gibberellic acid is a promising alternative for increasing germination speed and percentage in sweet corn seeds, particularly under stress conditions, where there is a marked reduction in viability. The poor quality of the seeds of this species, due to its intrinsic characteristics, justify the adoption of these practices to guarantee stand establishment in the field.

However, despite the advantages associated with pre-soaking with gibberellin, other methodologies, concentrations, and associations with growth regulators should be studied to establish the most appropriate and cost-effective procedure. 


\section{Conclusions}

Pre-soaking favors germination speed and percentage in sweet corn seeds, particularly under conditions of water stress.

In lots with a good physiological potential, pre-soaking with only water is sufficient to favor seed performance in most of the evaluated physiological characteristics.

In less vigorous lots, pre-soaking with $0.4 \mathrm{~g} \mathrm{~L}^{-1}$ gibberellic acid favors seed performance in all evaluated physiological characteristics.

\section{References}

Anese, S., Silva, E. A. A., Davide, A. C., Faria, J. M. R., Soares, G. C. M., Matos, A. C. B., \& Toorop, P. E. (2011). Seed priming improves endosperm weakening, germination, and subsequent seedling development of Solanum lycocarpum St. Hil. Seed Science and Technology, 39(1), 125-139. doi: 10. 15 258/sst.2011.39.1.11

Aragão, C. A., Dantas, B. F., Alves, E., Cataneo, A. C., Cavariani, C., \& Nakagawa, J. (2003). Atividade amilolítica e qualidade fisiológica de sementes armazenadas de milho super doce tratadas com ácido giberélico. Revista Brasileira de Sementes, 25(1), 43-48. doi: 10.1590/S0101-312220 03000100008

Bewley, J. D., Bradford, K. J., Hilhorst, H. W. M., \& Nonogaki, H. (2013). Seeds: physiology of development, germination and dormancy (3nd ed.). Nova York, NY: Springer.

Bezerra, A. M. E., Medeiros, S., Fo., Bruno, R. L. A., \& Momenté, V. G. (2006). Efeito da pré-embebição e aplicação de ácido giberélico na germinação de sementes de macela. Revista Brasileira de Sementes, 28(3), 185-190. doi: 10.1590/S0101-3122 2006000300026

Carvalho, N. M., \& Nakagawa, J. (2012). Sementes: ciência, tecnologia e produção. Jaboticabal: Funep.

Chen, K., Arora, R., \& Arora, U. (2010). Osmopriming of spinach (Spinacia oleracea L. cv. Bloomsdale) seeds and germination performance under temperature and water stress. Seed Science and Technology, 38(1), 36-48. doi: 10.15258/sst.2010.38.1.04

Cícero, S. M., \& Vieira, R. D. (1994). Teste de frio. In R. D. Vieira \& N. M. Carvalho (Eds.), Testes de vigor em sementes (pp. 151164). Jaboticabal: FUNEP/UNESP.

Dias, M. C. L. L., \& Barros, A. S. R. (1995). Avaliação da qualidade de sementes de milho. (Circular Técnica, 88). Londrina, PR: IAPAR.

Farhoudi, R., Saeedipour, S., \& Mohammadreza, D. (2011). The effect of $\mathrm{NaCl}$ seed priming on salt tolerance, antioxidant enzyme activity, proline and carbohydrate accumulation of Muskmelon (Cucumis melo L.) under saline condition. African Journal of Agricultural Research, 6(6), 1363-1370. Retrieved from https:// academicjournals. org/journal/AJAR/ article-full-text-pdf/64451C337638

Hu, J., Xie, X. J., Wang, Z. F., \& Song, W. J. (2006). Sand priming improves alfalfa germination under high-salt concentration stress. Seed Science and Technology, 34(1), 199204. doi: 10.15258/sst.2006.34.1.22

Kaya, M. D., Okçu, G., Atak, M., Çikili, Y., \& Kolsarici, Ö. (2006). Seed treatments to 
overcome salt and drought stress during germination in sunflower (Helianthus annuus L.). European Journal of Agronomy, 24(4), 291-295. doi: 10.1016/j. eja.2005.08.001

Lima, S. F., Jesus, A. A., Vendruscolo, E. P., Oliveira, T. R., Andrade, M. G. O., \& Simon, C. A. (2020). Development and production of sweet corn applied with biostimulant as seed treatment. Horticultura Brasileira, 38(1), 94-100. doi: 10.1590/S0102-05362 0200115

Lopes, H. M., \& Souza, C. M. (2008). Efeitos da giberelina e da secagem no condicionamento osmótico sobre a viabilidadeeovigordesementesdemamão (Carica papaya L.). Revista Brasileira de Sementes, 30(1), 181-189. doi: 10.1590/ S0101-31222008000100023

Luz, J. M. Q., Camilo, J. S., Barbieri, V.H. B., Rangel, R. M., \& Oliveira, R. C. (2014). Produtividade de genótipos de milho doce e milho verde em função de intervalos de colheita. Horticultura Brasileira, 32(2), 163-167. doi: 10.1590/S0102-05362014000200007

Maguire, J. D. (1962). Speed of germination-aid in selection and evaluation for seedling emergence and vigor. Crop Science, 2(2), 176-177. doi: 10.2135/cropsci1962.0011 183X000200020033x

Marcos, J., Fo., \& Kikuti, A. L. P. (2008). Condicionamento fisiológico de sementes de couve-flor e desempenho das plantas em campo. Horticultura Brasileira, 26(2), 165-169. doi: 10.1590/S0102-053 62008 000200007

Ministério da Agricultura, Pecuária e Abastecimento. (2009). Regras para análise de sementes. Brasília: MAPA/ACS. Recuperado de http://www.agricultura. gov.br/assuntos/laboratorios/arquivospublicacoesl aboratorio/regras-paraanalise-de-sementes.pdf/view

Mondo, V. H. V., Cicero, S. M., Dourado, D., Neto, Pupim, T. L., \& Dias, M. A. N. (2012). Vigor de sementes e desempenho de plantas de milho. Revista Brasileira de Sementes, 34(1), 143-155. doi: 10.1590/S0101-3122 2012000100018

Moreira, G. G., Viana, M. M., Lira, V. A., Guiscem, J. M., Santos, F. N., \& Rodrigues, E. F. (2014). Condicionamento fisiológico de sementes de melão com diferentes soluções de ácido giberélico e ácido salicílico. Horticultura Brasileira, 31(2), 652-659. Recuperado de http://www.abhorticultura. com.brl EventosX/Trabalhos/EV_7/ A6233_T9885_Comp.pdf

Oliveira, A. S., Silva-Mann, R., Santos, M. F., Gois, I. B., \& Barretto, M. C. V. (2007). Condicionamento osmótico em sementes de milho doce submetidas ao armazenamento. Revista Ciência Agronômica, 38(4), 444-448. Recuperado de http://ccarevista.ufc.br/seer/index.php/ ccarevista/article/view/108/103

Oliveira, E. A. de P., Zucareli, C., Prete, C. E. C. \& Zamuner, D. (2014). Potencial osmótico do substrato na germinação de sementes e desenvolvimento inicial de plântulas de milho doce. Revista Brasileira de Ciências Agrárias, 9(4), 477-482. doi: 10.5039/ agraria.v9i4a2625

Peixoto, C. P., Sales, F. J. S., Vieira, E. L., Passos, A. R., \& Santos, J. M. S. (2011). Ação da giberelina em sementes préembebidas de mamoneira. Comunicata Scientiae, 2(2), 70-75. Recuperado de https:// dialnet.unirioja.es/servlet/ articulo?codigo $=3884093$ 
Pereira, M. D., Dias, D. C. F. S., Dias, L. A. S., \& Araújo, E. F. (2009). Primed carrot seeds performance under water and temperature stress. Scientia Agricola, 66(2), 174-179. doi:10.1590/S0103-90162009000200005

Pimenta, R. M. B., Carvalho, T. G., Carvalho, R. S., Dantas, B. F., \& Aragão, C. A. (2010). Efeito da giberelina na qualidade fisiológica de sementes de berinjela. Horticultura Brasileira, 28(2), S4284-S4288. Recuperado de http:// ainfo.cnptia.embrapa.br/digital/bitstream/ item/18838/1/Barbara3_CBO_2010.pdf

Rabbani, A. R. C., Silva-Mann, R., Ferreira, R. A., \& Vasconcelos, M. C. (2013). Préembebição em sementes de moringa. Scientia Plena, 9(5), 1-8. Recuperado de https://www.scientiaplena.org.br/sp/ article/view/878/795

Santos, A. R. F., Silva-Mann, R., Ferreira, R. A., \& Brito, A. S. (2011). Water pre-hydration as priming for Moringa oleifera Lam. seeds under salt stress. Tropical and Subtropical Agroecosystems, 14(1), 201207. Recuperado de http://www.revista. ccba.uady.mx/ojs/index.php/TSA/article/ view/620/512
Souza, R. S., Vidigal, P. S., Fo, Scapim, C. A., Marques, O. J., Queiroz, D. C., Okumura, R. S.,... Cortinove, R. S. (2013). Produtividade e qualidade do milho doce em diferentes populações de plantas. Semina: Ciências Agrárias, 34(3), 995-1010. doi: 10.5433/1679-0359.2013v34n3p995

Storck, L., Lovato, C., \& Comassetto, V. (1984). Avaliação do rendimento e outras características agronômicas de cultivares de milho doce. Revista do Centro de Ciências Rurais, 14(3-4), 153160. Recuperado de http://coral.ufsm. br/revistaccr/index.php/RCCCR/article/ view/534/533

Taiz, L., \& Zeiger, E. (2013). Fisiologia vegetal (5nd ed.). Porto Alegre: Artmed.

Taylor, A. G., Allen, P. S., Bennett, M. A., Bradford, K. J., Burris, J. S., \& Misra, M. K. (1998). Seeds enhancements. Seed Science Research, 8(2), 245-256. doi: 10.1017/ S0960258500004141

Varier, A., Vari, A. K., \& Dadlani, M. (2010). The subcellular basis of seed priming. Current Science, 99(4), 450-456. Recuperado de http://www.mendeley.com/research/ subcellular-basis-seed-priming/ 
